\title{
Artesanias, empregos e economia urbana
}

\author{
Ewerton Reubens Coelho-Costa
}

OCEJO, R.E. Masters of craft: old jobs in the new urban economy. Princeton, NJ: Princeton University Press, 2017. 368 p.

A obra "Masters of craft: Old jobs in the new urban economy", publicada em língua inglesa, ainda não apresenta edição traduzida no Brasil. Richard E. Ocejo, doutor em Sociologia pela City University of New York (CUNY) e, atualmente, é professor associado da CUNY ensinando na Doctoral Faculty in Sociology, no Departamento de sociologia do Jay College of Criminal Justice e no Doctoral Faculty in Criminal Justice. Dedica-se a pesquisas com foco na sociologia urbana e cultural, estudos comunitários, trabalho e ocupações e métodos de pesquisa, especialmente qualitativos.

A obra é composta de duas partes onde se dividem oito capítulos, como se pode ver a seguir: Introduction. A Stroll Through The Market; Part I - 1 The Cocktail Renaissance; 2 Distilling Authenticity; 3 Working On Men; 4 Show The Animal; Part II - 5 How Middle-Class Kids Want Working-Class Jobs; 6 The Science And The Art; 7 Service Teaching; 8 Getting The Job; Epilogue. Outcomes, Implications, and Concluding Thoughts; Methodological Appendix; Notes; References; Index.

Considerando que nesse período atual, pós-recessão, muitos trabalhos manuais quase desapareceram, é importante encontrar na literatura pesquisas que se dediquem ao estudo e análise sobre a mudança do significado social dos empregos e os trabalhos estéticos. Por esse motivo, justifica-se o interesse na leitura de "Masters of craft: Old jobs in the new urban economy", que apresenta

\section{$\overline{\text { Ewerton Reubens Coelho-Costa }}$}

Doutorando em Sociologia pela Universidade Estadual do Ceará - UECE; Mestre em Gestão de Negócios Turísticos - UECE; Graduado em Gestão do Turismo (IFCE); Membro do Grupo de Pesquisa Gestão do Turismo e da Hospitalidade nos Territórios (IFCE); E-mail.: ewertonreubens@hotmail.com 
como jovens educados e "culturalmente experientes" transformam trabalhos manuais que, geralmente, têm baixo status em ocupações de produção de gosto das elites.

Considerando ainda que, na economia da atualidade, os "bons" empregos estão caracteristicamente baseados no uso de novas tecnologias e na necessidade de conhecimento, a obra de Ocejo analisa o renascimento de quatro ofícios que lidam com trabalho manual de baixo status: bartender, destilador, barbeiro e açougueiro.

Em contexto cativante e aprofundado, Richard Ocejo leva o leitor a desbravar a vida e os locais de trabalho de pessoas que transformaram trabalhos de baixo status em nichos de ocupação que, pela alta especialidade, levam seus detentores a serem identificados como representantes de nichos de luxo e "cool" - mostrando o processo sofisticado de mobilidade descendente e ascendente pelo trabalho.

O autor evidencia como os artífices usaram seus repertórios culturais para dar nova roupagem a esses trabalhos explorando habilidades técnicas e senso de renovação de artesanias, além de gerar habilidades e capacidades para comunicar e compreender seus conhecimentos e combiná-los com outros para resultar em "gostos de elite". Ocejo percorre ainda os caminhos trilhados pelos artífices em seus empregos, examinando como eles aprenderam seus ofícios, como empregam suas práticas e habilidades de trabalho e como ensinam um senso de gosto a seus consumidores.

Partindo das figuras de um açougueiro, um barbeiro, um bartender de coquetéis e um fabricante de uísque artesanal que caminham pelas ruas do Brooklyn, Ocejo apresenta semelhanças entre as quatro ocupações: em todas existem homens urbanos oferecendo trabalhos feitos pelas mãos e bastante pensados pela cabeça - o que ajudou a desenvolver preferências estéticas para consumidores urbanos em paisagens mais gentis. Fica evidente que três dos quatro ofícios analisados (bartender, destilador e açougueiro) estão conectados com o mundo da gastronomia. Esses artífices não apenas preparam bebidas artesanais ou cortam carne: eles vão além, transmitem importantes informações aos consumidores sobre como se envolver no mundo da carne e da bebida de alta qualidade, explorando o que de melhor os insumos e as técnicas podem oferecer. 
Um ponto positivo da obra é a criatividade de Ocejo em fazer ligações entre as ocupações com uma abordagem criativa: o autor constrói o texto a partir dos mundos materiais do álcool, do cabelo e da carne com a visão de homens urbanos e traça percepções conceituais partindo de múltiplos campos e subcampos relacionados à cultura, à cidade, à masculinidade, ao trabalho e ao consumo, trabalhando etnograficamente as quatro ocupações a partir de trabalhos executados na cidade de Nova York e evidenciando o funcionamento das ocupações e os desafios dos trabalhos.

O autor explicita o perfil dos homens que trabalham com essas ocupações: são frequentemente bem-educados, sofisticados culturalmente e estão buscando trabalhos cheios de significados que lhes afastem do mundo engessado e enclausurado dos escritórios. Em cada ofício eles observaram a oportunidade de se aprimorarem em produtos que lhes fizeram apaixonarem-se e que lhes possibilitam moldar também, pela criatividade, os gostos dos consumidores.

Ocejo deixa claro que são mão de obra e trabalhadores de elite esses novos artífices dos coquetéis, da barbearia, da destilação e do açougue; eles recriam ocupações antes indesejadas em cobiçados nichos de mercado, bem aceitos mercadologicamente, taxados de "cool" e repletos de qualificação e especialidade pensada propositalmente para o bem atender. Apesar de alguns dos trabalhadores apresentados serem mulheres, a obra se refere basicamente a homens que ocupam esses empregos - o que talvez seja um ponto negativo para o livro, mas que não o desqualifica como boa leitura.

A obra propicia ao leitor a compreensão da cultura como marcador de status em produções culinárias não como práticas anônimas, mas como produtos do pensamento sofisticado de artífices com habilidades e bastante conhecimento que acabam se tornando atores fundamentais na construção da estética cultural e gastronômica.

A linguagem clara e coesa faz valer a leitura da obra, que leva o leitor a se impressionar com a teia de informações criada a partir do contexto histórico dos mundos da mixologia, destilação, barbearia e do açougue, temperados com insights sociológicos 
e um engendrado de detalhes etnográficos bem costurados. No entanto, para discussões futuras, seria interessante o autor resgatar a ideia ampliada do livro, demonstrando como essas ocupações se enquadram no mundo de trabalho marcado pela desigualdade, abordando questões de classe e gênero, talvez. Ou, simplesmente, levantar o feminismo e analisar as ocupações a partir da visão feminina, reescrevendo cada ofício e as dificuldades e facilidades a partir do gênero, dos fluxos de trabalho e da remuneração de serviços - principalmente quando se sabe que as mulheres ainda ganham menos que homens pelos mesmos trabalhos. Um questionamento surgiu com o final da leitura: para os casos apresentados pela obra, estariam os ofícios com alto status, sobretudo na alimentação, fincados numa base de sexismo e recorte racial?

Outro alerta que surgiu com a leitura diz respeito à tensão dinâmica entre a abertura democrática e a distinção cultural gastronômica de alto padrão - as quais geralmente partem da democratização estética, e os trabalhadores que se esforçam para ampliar gostos muitas vezes tratam de educar seus clientes para possibilitar novas criações e discutir qualidade.

Essa "educação" de consumidores, no que tange ao gosto, parece reproduzir distinções que acabam gerando o que os artífices entendem como status, mas que podem ser, perfeitamente, reproduções das desigualdades intersetoriais que estratificam a cultura. Esses trabalhadores de elite desencadeiam novos gostos, mas também criam fronteiras, por exemplo, para pessoas que não têm "paladares educados" - ou, simplesmente, acabam comunicando a pessoas que seus gostos e cultura estão deficientes, ruins ou fora de moda, pois não foram "educados".

Talvez por ter seguido esse mesmo pensamento, Ocejo descreve ao longo do texto interações onde os trabalhadores percebem os consumidores como "confusos", "perdidos" ou mesmo "idiotas". Por isso, fica evidente que esses trabalhadores e mãos de obra de serviços de elite são influentes educadores de gosto, mas também devem ser especialistas no esnobismo de alimentos e bebidas. Além disso, precisam ser guardiões da cultura e estar ligados também às tensões de cada campo - devem ser guardiões artesãos antes de serem freelancers em ofícios. 
Finalmente, trata-se de uma obra cuja leitura é recomendada para acadêmicos e curiosos da alimentação, antropologia e ciências sociais, principalmente aqueles dedicados a pesquisas, ou meros curiosos da gentrificação nas cidades e das transformações do trabalho a partir da criatividade - além de fornecer uma fascinante visão da nova economia urbana, que possibilita discutir questões de cultura, consumo e trabalho nas cidades. 